\title{
Effect of Angiotensin II on Secretion of Adrenal Androgens
}

\author{
Toshiniko YANASE, Toshio MAKI, \\ Hajime NAWATA, KeN-ICHI KATO AND \\ HIROSHI IBAYASHI
}

Third Department of Internal

Medicine, Faculty of Medicine, Kyushu University, Fukuoka 812

\begin{abstract}
To assess the effect of angiotensin II (A II) on the secretion of human adrenal androgens (AA), plasma dehydroepiandrosterone (DHEA), DHEA sulfate (DS) and $\Delta^{4}$-androstenedione $\left(\Delta^{4}\right.$-A) were measured in eight normal men 60 and 120 min after stimulationn of endogenous A II by a bolus injection of $40 \mathrm{mg}$ frusemide, and the direct effect of A II on the secretion of adrenal androgens was examined in cultured human adrenocortical cells in the presence of a low concentration of ACTH.

The administration of frusemide led to a significant increase in the plasma DHEA and DS concentration as well as plasma renin activity (PRA) and aldosterone concentration (PAC), but did not change plasma cortisol and $\Delta^{4}$-A. In the culture of human adrenocortical cells, $10^{-9}-10^{-5} \mathrm{M}$ A II or $10^{-13} \mathrm{M}$ ACTH alone did not stimulate the secretion of DHEA, DS and $\Delta^{4}$-A, while $10^{-7}$ and $10^{-5} \mathrm{M} \mathrm{A}$ II in the presence of $10^{-13} \mathrm{M} \mathrm{ACTH}$ caused a significant increase in DHEA and DS secretion with no change in $\Delta^{4}$-A. These results suggest that the activated renin-angiotensin system stimulates the secretion of adrenal androgens by a direct effect of A II on adrenal cortical cells.
\end{abstract}

Although ACTH is widely accepted to be a main stimulator of adrenal androgens (Parker and Odell, 1980), the existence of other modulators has been hypothesized on the basis of clinical observations, including the less marked suppression of AA than of cortisol by dexamethasone (Nishida et al., 1979) and the increased AA secretion during adrenarche (De Peretti and Forest, 1976; Parker et al., 1978) and puberty when the plasma ACTH level is unchanged (Hopper

Received July 16, 1984 and Yen, 1975). Many candidates such as estrogens, prolactin, gonadotropin and growth hormone have been proposed as factors modulating AA secretion but most of them still remain unestablished in this role (Parker and Odell, 1980). Higuchi et al. (1982) demonstrated the direct effect of human prolactin on AA secretion in cultured human adrenocortical cells. Recently, it was reported that a human pituitary glycopeptide stimulates AA secretion (Parker et al., 1983).

On the other hand, relatively little attention has been paid to the action of the 
renin-angiotensin system on AA secretion. The possibility that A II can stimulate AA secretion has been suggested by the results of studies on the salt-losing syndrome of congenital adrenal hyperplasia, which is characterized by elevated PRA (Horner et al., 1979; Schaison et al., 1980). Parker et al. (1983) clearly demonstrated the direct stimulatory effect of A II in the presence of a physiological concentration of ACTH in canine adrenal cell suspensions. In the present study, we examined the effect of A II on AA secretion by activating the reninangiotensin system in vivo and re-evaluated the direct effect of A II on AA secretion in isolated human adrenocortical cells in primary monolayer culture.

\section{Materials and Methods}

\section{Frusemide test}

Eight healthy men, aged 19-28 yr. (20.9 \pm 3.0 , mean \pm SD) participated in the present study. The subjects showed no evidence of any medical disorder and they were on a normal sodium diet $(10 \mathrm{~g} \mathrm{NaCl} /$ day $)$. Following successive recumbency after they were awake, frusemide tests were performed between 08.00 and $10.00 \mathrm{~h}$. Immediately after taking blood samples at zero time, a bolus injection of $40 \mathrm{mg}$ frusemide (Lasix, Hoechst) was given. Venous blood samples were obtained at 60 and $120 \mathrm{~min}$ after the injection for measurements of plasma renin activity (PRA), aldosterone concentration (PAC), cortisol, DHEA, DS and $\Delta^{4}$-A. During the tests, the subjects were allowed to stand only when they went to the lavatory.

\section{Cell preparation}

A human normal adrenal gland was obtained from a $37 \mathrm{yr}$. old woman who underwent left adrenectomy as part of the surgical therapy for breast cancer. After as much of the adrenal medulla tissue was excluded as possible, the total cortex tissue was minced, incubated with Minimum Essential Medium (MEM) (GIBCO) containing $10 \%$ collagenase (Sigma, type I) and gently stirred at $37^{\circ} \mathrm{C}$ for $60 \mathrm{~min}$. After filtration through gauze mesh, the cells were washed with
MEM three times and plated in plastic dishes (Corning $35 \mathrm{~mm}$ ). Each dish contained $1 \times 10^{5}$ cells in $1 \mathrm{ml}$ of MEM supplemented with $10 \%$ fetal calf serum (FCS) (GIBCO). The cells were incubated at $37^{\circ} \mathrm{C}$ in $5 \% \mathrm{CO}_{2}-95 \%$ air. The media were daily renewed and the experiments were initiated 3 days after plating.

\section{Secretion experiments}

After each plate was replaced with FCS-free MEM, $10^{-9}, 10^{-7}$ and ${ }^{-5} \mathrm{M}$ angiotensin II (Hypertensin, Ciba) and/or $10^{-13} \mathrm{M}$ ACTH (Acthormon, Shionogi) were added. After $180 \mathrm{~min}$ incubation, the medium was collected from individual plates for subsequent measurement of cortisol, aldosterone, DHEA, DS and $\Delta^{4}$-A. All data reported were means $\pm S E$ of triplicate incubation.

\section{Extraction and assay}

PRA and PAC were measured by RIA using the kits of Le Commissariat A L'Energie Atomique, France. Aldosterone in cultured medium was extracted by dichlormethane, evaporated, reconstituted with charcoal-treated FCS which was free from steroids, and measured using the above kits. Cortisol in plasma and medium was measured by RIA using kits of Dai-ichi Radioisotope, Tokyo. The lower limits of sensitivity were 0.25 $\mathrm{ng} / \mathrm{ml} / \mathrm{hr}$ for PRA, $25 \mathrm{pg} / \mathrm{ml}$ for PAC and 0.6 $\mu \mathrm{g} / \mathrm{dl}$ for cortisol. The interassay coefficent of variation (CV) was $9.2 \%$ for PRA $7.7 \%$ for PAC, and $14 \%$ for cortisol. In the measurement of DS in plasma and medium, the samples were extracted with ethylalcohol, evaporated and measured directly by specific RIA. In measurement of DHEA and $J^{4}$-A in plasma and medium, the samples were extracted with diethylether and separated using a Sephadex LH-20 column (Hexane: Benzene: Methanol=80:10:10). Each fraction was measured by specific RIA for DHEA or $\Delta^{4}$-A. The lower limits of sensitivity were $10 \mathrm{ng} / \mathrm{ml}$ for DS, $0.1 \mathrm{ng} / \mathrm{ml}$ for DHEA, and $0.1 \mathrm{ng} / \mathrm{ml}$ for $\Delta^{4}$-A. Interassay $\mathrm{CV}$ values were $13 \%$ for DS, $11 \%$ for DHEA, and $14 \%$ for $\Delta^{4}$-A. Intraassay $\mathrm{CV}$ values were $6 \%$ for DS, $8 \%$ for DHEA, and $5 \%$ for $\Delta^{4}$-A. Specific antibodies to DS were kindly supplied by Dr. H. Sekihara (Sekihara and Osawa, 1974). Specific antibodies to DHEA and $\Delta^{4}$-A were obtained from Teikoku Hormone Mfg. Co., Ltd. Tokyo. Sephadex LH-20 was obtained from Pharmacia Fine Chemicals. 


\section{Statistical methods}

The statistical significance of the data was assessed using Student's $t$-test. It was $t$-dependent in vivo and $t$-independent in in vitro experiments.
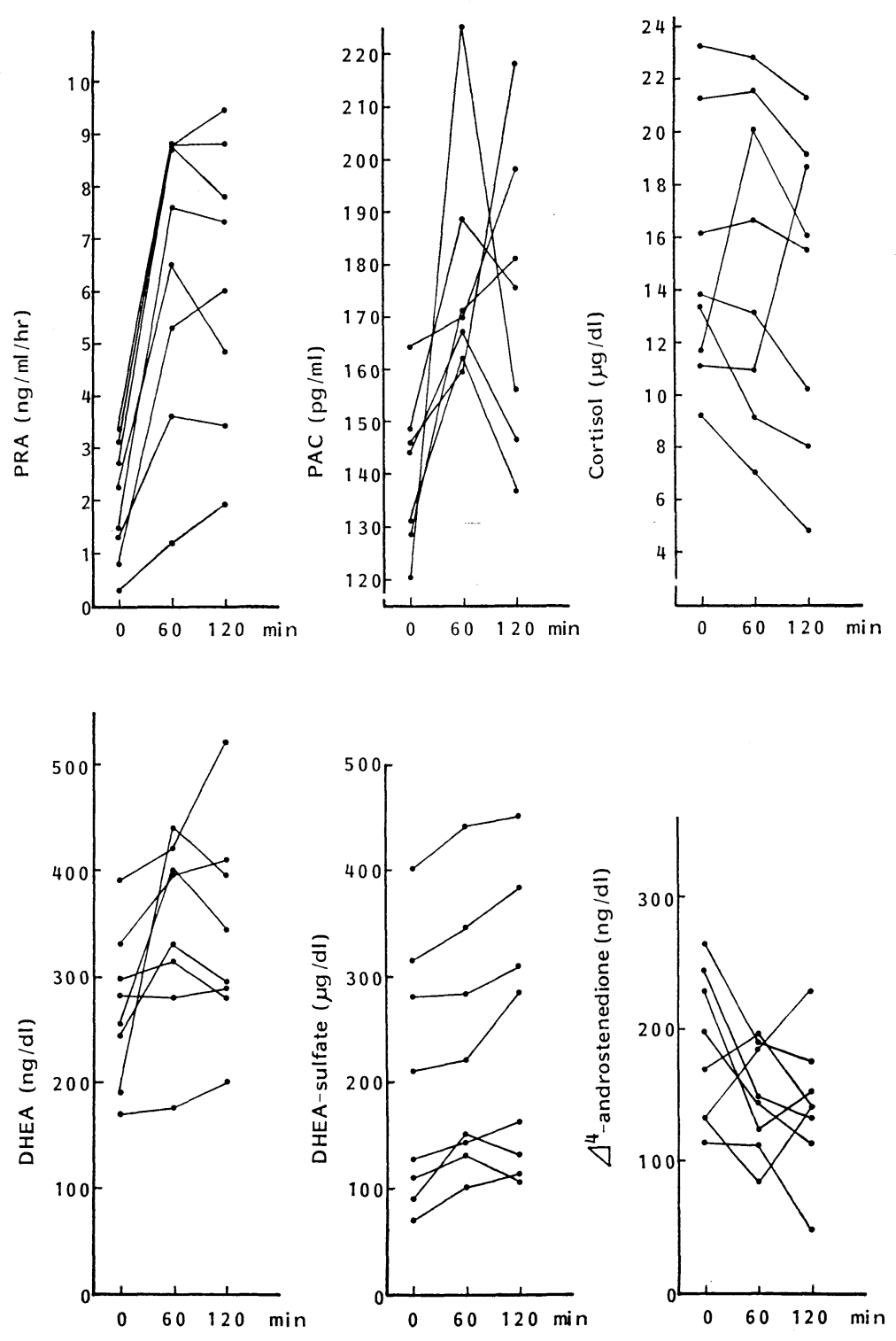

\section{Results}

\section{Frusemide test}

Individual basal concentrations and responses of PRA, PAC, DHEA, DS and $\Delta^{4}$-A in the frusemide test on eight healthy men are shown in Fig. 1. The statistical com-

Fig. 1. Responses of plasma renin activity (PRA), plasma aldosterone concentration (PAC), plasma cortisol, dehydroepinadrosterone (DHEA), DHEA-sulfate (DS) and $\Delta^{4}$ androstenedione $\left(\Delta^{4}\right.$-A) to bolous intravenous injection of frusemide $(40 \mathrm{mg})$ in eight normal subjects. 
Table 1. Statistical comparisons of PRA, PAC, plasma cortisol, DHEA, DS and $\Delta^{4}$-A in frusemide test. Values are given as mean \pm SD.

\begin{tabular}{lccc}
\hline \hline & 0 & 60 & $120 \mathrm{~min}$ \\
\hline PRA & 1.90 & $6.32^{* *}$ & $6.19^{* *}$ \\
$(\mathrm{ng} / \mathrm{ml} / \mathrm{hr})$ & \pm 1.08 & \pm 2.80 & \pm 2.65 \\
PAC & 139.3 & $177.7^{*}$ & $171.9^{* *}$ \\
$(\mathrm{pg} / \mathrm{ml})$ & \pm 13.9 & \pm 24.7 & \pm 27.2 \\
Cortisol & 15.0 & 15.2 & 14.2 \\
$(\mu \mathrm{g} / \mathrm{dl})$ & \pm 4.9 & \pm 6.0 & \pm 5.9 \\
DHEA & 270.9 & 346.4 & $342.0 *$ \\
$(\mathrm{ng} / \mathrm{dl})$ & \pm 72.0 & \pm 92.4 & \pm 99.3 \\
$\mathrm{DS}$ & 201.0 & $224.5^{* *}$ & $241.3^{* *}$ \\
$(\mu \mathrm{g} / \mathrm{dl})$ & \pm 120.1 & \pm 121.3 & \pm 133.7 \\
$\Delta^{4}-\mathrm{A}$ & 185.9 & 147.5 & 140.9 \\
$(\mathrm{ng} / \mathrm{dl})$ & \pm 55.6 & \pm 38.5 & \pm 52.3 \\
\hline$*$ & $*_{\mathrm{p}}<0.05$, & $* * \mathrm{p}<0.01$ & $\mathrm{vs}$
\end{tabular}

parisons are shown in Table 1. PRA, PAC and DS were significantly increased at 60 and $120 \mathrm{~min}$ after frusemide injection. DHEA was significantly increased at 120 min. On the other hand, no significant change in plasma $\Delta^{4}$-A or cortisol was observed.

Effect of $A$ II in cultured human adrenocortical cells

Effects of A II and/or $10^{-13} \mathrm{M}$ ACTH on the secretion of aldosterone, cortisol, DHEA, DS and $\Delta^{4}$-A in cultured human adrenocortical cells are shown in Fig. 2.
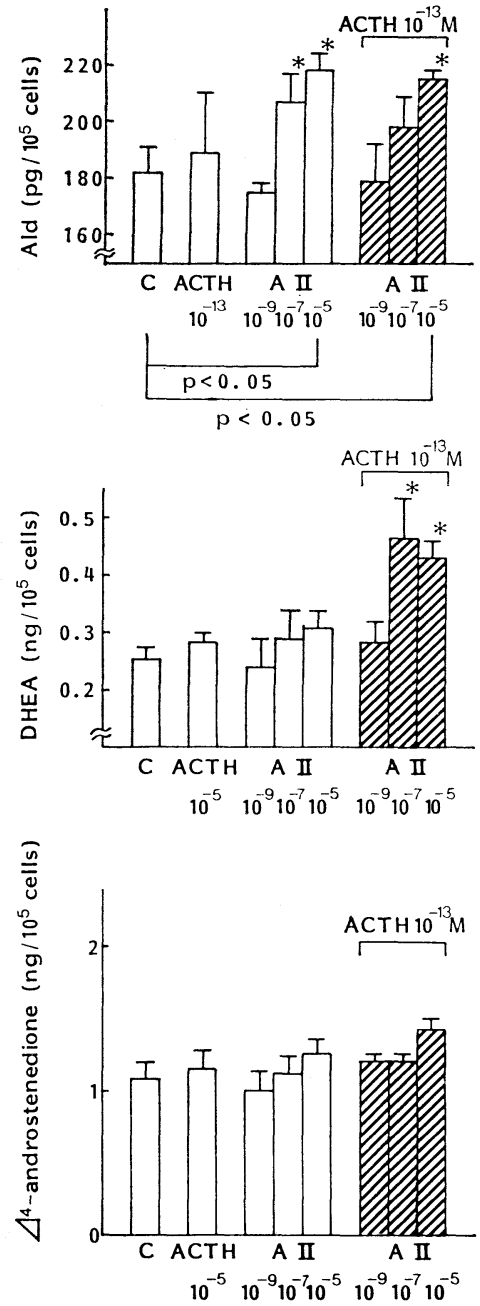
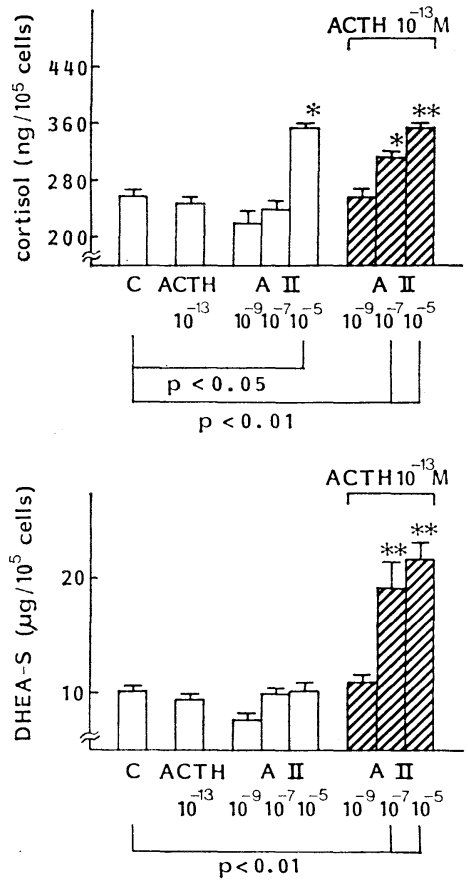

Fig. 2. Effect of various concentrations of A II and/or $10^{-13} \mathrm{M}$ ACTH on the secretion of aldosterone, cortisol, DHEA, DS and $\Delta^{4}$-A in human adrenocortical cells in primary monolayer culture. Values are given as mean \pm S.E. of triplicate dishes. ${ }^{*} \mathrm{p}<0.05$. ** $\mathrm{p}<0.01$. 
$10^{-9}-10^{-5} \mathrm{M}$ A II stimulated the secretions of aldosterone and cortisol in a dose dependent manner from human adrenocortical cells in the primary monolayer culture. $10^{-13} \mathrm{M}$ ACTH did not stimulate the secretion of DHEA, DS or $\Delta^{4}$-A. However A II in combination with $10^{-13} \mathrm{M}$ ACTH caused significant increases in DHEA and DS secretion in a dose dependent manner without any change in $\Delta^{4}$-A.

\section{Discussion}

The possibility that A II can affect AA secretion has been shown in patients with adrenal 21-hydroxylase deficiency (Horner et al., 1979; Scahison et al., 1980). In contrast, Wisgerhof et al. (1983) reported the failure of A II to cause AA secretion in a patient with adrenal 21-hydroxylase deficiency. To our knowledge, no in vivo data are available on the effect of the reninangiotensin system on AA secretion in normal subjects. The results of our present in vivo study indicate that the activated reninangiotensin system may stimulate human adrenocortical cells and increase the secretion of AA even in physiological conditions. The absence of a change in the plasma cortisol level during the test rules out the possibility that frusemide induced stress or that A II increased ACTH (Rayyis and Horton, 1974) which in turn enhanced the secretion of DHEA and DS.

Our in vitro data clearly indicate that A II can directly stimulate the secretion of DHEA and DS in the presence ACTH. This result is in accordance with the report of Parker et al. (1983) that A II, in concentrations of $4 \times 10^{-10} \mathrm{M}$ and above, was capable of stimulating DHEA production in the presence of $10^{-13} \mathrm{M} A C T H$ in canine adrenal cell suspensions. A similar synergistic effect has been demonstrated with a combination of ACTH and prolactin on the corticosterone production of isolated rat adrenal cells (Lis et al., 1974) and AA production of human adrenocortical cells (Higuchi et al., 1982). These facts suggest that ACTH may be essential for the maintainance of adrenal enzyme for $\Delta^{5}$-steroids and facilitate the full response of $\mathrm{AA}$ to $\mathrm{A}$ II or prolactin. Our in vivo data showed that higher concentrations of $\mathrm{A}$ II were required to obtain a more significant increase in AA and aldosterone than that found by Parker et al. (1983). The lower sensitivity of human adrenocortical cells to A II may be due to changes in cell membranes by the dispersing cells in the culture or due to the degradation of A II in the media. Our in vitro data, showing a concomitant increase in DHEA and DS in line with the increase in aldosterone due to A II in the presence of $10^{-13} \mathrm{M}$ ACTH, seem to reflect a physiological response considering the intimate and well established relationship between A II and aldosterone (Fraser et al., 1979). From the findings on the increase in DHEA due to A II, Parker et al. (1983) speculated that the effect of A II was on the adrenal enzyme 17-20 desmolase but precursor steroids were not measured. This speculation seems to be impossible in the light of our observation of increased DHEA and DS with no change in $\Delta^{4}$-A. At present, it is difficult to conclude which step has to do with the increase in AA due to A II.

In our experiments, cortisol was distinctly stimulated by $10^{-5} \mathrm{M}$ A II. The direct stimulation of cortisol by A II in isolated human adrenocortical cells has also been reported by other investigators (McKenna et al., 1978; Belmeger et al., 1983). Even in adrenal adenomas, a concomitant production of aldosterone and cortisol has been noted (Komiya et al., 1979; Belmeger et al., 1983). The effect of A II on cortisol production might be mediated by A II receptors on zona fasciculata cells (Vallotton et al., 1981), or shared with the additional effect of A II on late biosynthetic steps in zona glomerulosa (Fraser et al., 1979). On the other 
hand, we observed no change in plasma cortisol when the renin-angiotensin system was activated. A fall in the level of plasma cortisol or its failure to rise during A II infusion has been reported by many investigators (Hollenbergs et al., 1974; Oelkers et al., 1974, 1975; McKenna et al., 1978), These divergent results on the effect of A II on cortisol in vivo and in vitro might be explained by the fact that cortisol stimulation by A II in vivo is immediately counterbalanced by a fall in the plasma ACTH concentration (Semple et al., 1979).

To sum up, the results of the study reported here indicate that the activated reninangiotensin system stimulates the secretion of adrenal androgens through a direct effect of A II on the adrenal cortical cells.

\section{References}

Belmeger, W., W. Oelkers, L. Belkien, M. Shirpai, V. Fiedler, and R. Häring (1983). Effect of angiotensin II and ACTH on normal and tumourous human adrenocortical cells. Acta. Eudocrinol. 104, 103-109.

De Peretti, M. and M. Forest (1976). Unconjugated DHA plasma levels in normal subjects from birth to adolescence. J. Clin. Endocrinol. Metab. 46, 396-401.

Fraser, R., J. J. Brown, A. F. Lever, P. A. Mason and J. I. S. Robertson (1979). Control of aldosterone secretion. Clin. Sci. 56, 389-399.

Higuchi, K., Nawata, T. Maki, M. Higashijima, K. Kato and H. Ibayashi (1982). Prolactin and adrenal androgen. Folia Endocrinol. Jpn. 58, 1228.

Hollenberg, N. K., W. R. Chenitz, D. F. Adams and G. H. Williams (1974). Reciprocal influence of salt intake on adrenal glomerulosa and renal vascular responses to angiotensin II in normal man. J. Clin. Invest. 54, 34-42.

Hopper, B. and S. Yen (1975). Circulating concentrations of DHA and DHAS during puberty. J. Clin. Endocrinol. Metab. 40, 457-461.

Horner, J. M., R. L. Hintz and J. A. Luetscher (1979). The role of renin and angiotensin in salt-losing, 21-hydroxylase deficient congenital adrenal hyperplasia. J. Clin. Endocrinol. Metab. 48, 776-783.
Komiya, I., Y. Koizumi, R. Kobayashi, M. Kotani, F. Yamada and U. Maruyama (1979). Concurrent hypersecretion of aldosterone and cortisol from the adrenal cortical adenoma. Am. J. Med. 67, 516-518.

McKenna, T. J., D. P. Island, W. E. Nicholson and G. W. Liddle (1978). Angiotensin stimulates cortisol biosynthesis in human adrenal cells in vitro. Steroids, 32, 127-136.

Lis, M., D. W. Giladeau and M. Chretien (1974). Effect of prolactin on corticosterone production by rat adrenals. Clinical Research, 21, 1027.

Nishida, S., S. Matsumura, M. Horino, M. Matsuki, H. Oyama, A. Tenku, K. Kakita, H. Tanaka and Y. Omukai (1979). Dexamethasone suppressibility of plasma pregnenolone or DHEA in gonadectomized patients. Steroids, 34, 471476.

Oelkers, W., J. J. Brown, R. Fraser, A. F. Lever, J. J. Morton and J. I. S. Robertson (1974). Sensitization of the adrenal cortex to angiotensin II in sodium-deplete men. Circ. Res. 34, 69-77.

Oelkers, W., M. Schöneshöfer, G. Schultze, J. J. Brown, R. Fraser, J. J. Morton, A. F. Lever and J. I. S. Robertson (1975). Effect of prolonged low-dose angiotensin II infusion on the sensitivity of adrenal cortex in man. Circ. Res. 36, supple. 1, 49-56.

Parker, L., J. Sack, D. Fisher and D. Odell (1978). The adrenarche: prolactin, gonadotropin adrenal androgens and cortisol. J. Clin. Endocrinol. Metab. 46, 396-401.

Parker, L. N. and W. D. Odell (1980). Control of adrenal androgen secretion. Endocrine. Rev. 1, 392-410.

Parker, L. N., E. T. Lifrak, C. K. Kawahara, S. I. Geduld and X. M. Kozbur (1983). Angiotensin II potentiates ACTH-stimulated adrenal androgen secretion. J. Steroid. Biochem. 18, 205-208.

Parker, L. N., E. T. Lifrak and W. D. Odell (1983). A 60,000 molecular weight human pituitary glycopeptide stimulates adrenal androgen secretion. Endocrinology, 113, 20922096.

Rayyis, S. S. and R. Horton, (1974). Effect of angiotensin II on adrenal and pituitary function in man. J. Clin. Endocrinol. Metab. 32, 539-546.

Schaison, G., B. Couzinet, M. Gourmelen, F. Elkik and P. Bougneres (1980). Angiotensin and adrenal steroidogenesis: study of 21-hydroxylase-deficient congenital adrenal hyper- 
plasia. J. Clin. Endocrinol. Metab. 51, 13901394.

Sekihara, H. and N. Ohsawa (1974). A radioimmunoassay for serum 11-deoxy-17-ketosteroids. Steroids, 23, 245-258.

Semple, P. F., J. C. Buckingham, P. A. Mason and R. Fraser (1979). Suppression of plasma ACTH concentration by angiotensin II infusion in normal humans and in a subject with a steroid $17 \alpha$-hydroxylase defect.. Clin. Endocrinol. $($ Oxf $), 10,137-144$.

Vallotton, M. B., A. M. Capponi, C. H. Grillet,
A. I. Knupfer, R. Hepp, M. C. Khosla and F. M. Bumpus (1981). Characterization of angiotensin receptors on bovine adrenal fasciculata cells. Proc. Nat. Acad. Sci. USA. 78, 592-596.

Wisgerhof, M., R. C. Mellinger and M. S. Zofer (1983). Failure of angiotensin II to stimulate increases in concentrations of adrenal androgens, 17-hydroxyprogesterone, of adreno-corti cotropin in congenital 21-hydroxylase deficiency J. Clin. Endocrinol. Metab. 56, 627-631. 